Studia i materiały $\mathrm{z}$ dziedzictwa kulturowego Torunia i regionu, t. 1: STARE I NOWE DZIEDZICTWO TORUNIA,

Toruń 2013

http://dx.doi.org/10.12775/SiMzDzKTiR_T1.2013.011

Ewelina Nawrocka

(TORUŃ)

\title{
Kamienica przy Rynku Staromiejskim 20 w Toruniu Analiza zabytkoznawcza budynku
}

Niniejszy artykuł jest oparty na dokumentacji ${ }^{1}$, wykonanej w 2011 r. na podstawie szczegółowych badań kamienicy, po usunięciu tynków wewnętrznych, a przed planowanym remontem budynku. W opracowaniu, poza częścią opisową, zawarta jest obszerna dokumentacja fotograficzna oraz rzuty i przekroje obiektu z graficznym przedstawieniem wyników badań (il. 1-7). Równolegle w budynku prowadzone były też badania malarskiego wystroju wnętrza (Anna Bystroń Kwiatkowska ${ }^{2}$ ) oraz badania dendrochronologiczne (Aleksander Konieczny ${ }^{3}$ ). Autorem projektu nowej adaptacji jest Lucyna Czyżniewska. W 2008 r. tematem kamienicy przy Rynku Staromiejskim 20 w Toruniu zajmował się Robert Paszkowski, który wykonał dokumentację w oparciu o badania z odkrywkami fragmentarycznymi oraz kwerendę archiwalną ${ }^{4}$.

1 Ewelina NAWROCKA, Kamienica przy Rynku Staromiejskim 20 w Toruniu. Analiza zabytkoznawcza budynku (konsultacje Zbigniew NAWROCKI), [kps] Toruń 2011 r., archiwum MKZ Toruń, sygn. 4486. Dokumentacja ta, stanowiąca podstawę artykułu, zawiera dodatkowo szczegółowy opis poszczególnych punktów oznaczonych na planszach oraz dokładne wytyczne konserwatorskie dla wszystkich poziomów budynku. Pragnę podziękować Panu Zbigniewowi Nawrockiemu za wiele cennych wskazówek, dotyczących tematu.

2 Anna BYSTROŃ KWIATKOWSKA, Dokumentacja prac konserwatorskich i restauratorskich. Polichromowany strop dylowo-belkowy parteru tylnego traktu kamienicy przy Rynku Staromiejskim 20 w Toruniu, [kps] Toruń 2011 r., archiwum MKZ Toruń, sygn. 5077/4; TAŻ, Dokumentacja prac konserwatorskich i restauratorskich. Polichromowany strop belkowo-deskowy 1 piętra tylnego traktu kamienicy przy Rynku Staromiejskim 20 w Toruniu, [kps] Toruń 2011 r., archiwum MKZ Toruń, sygn. 5077/3; Anna SOCHA-BYSTROŃ, Dokumentacja prac konserwatorskich prowadzonych przy polichromowanym stropie drewnianym wysokiej sieni kamienicy przy Rynku Staromiejskim 20 w Toruniu, [kps] Toruń 2011 r., archiwum MKZ Toruń, sygn. 5077/2; TAŻ, Dokumentacja prac konserwatorskich prowadzonych przy stropie płóciennym z tylnego traktu parteru kamienicy przy Rynku Staromiejskim 20 w Toruniu, [kps] Toruń 2011 r., archiwum MKZ Toruń, sygn. 5077/1. Por. artykuł tej autorki w niniejszym tomie.

3 Aleksander KONIECZNY, Ekspertyza dendrochronologiczna. Toruń, kamienica Rynek Staromiejski 20, [kps] Toruń marzec 2011 r., archiwum MKZ Toruń, sygn. 4489; Tegoż, Ekspertyza dendrochronologiczna, Toruń, kamienica Rynek Staromiejski 20, [kps] Toruń marzec 2007 r., archiwum MKZ Toruń, sygn. 3803, 3776.

4 Robert PASZKOWSKI, Toruń, kamienica Rynek Staromiejski 20. Dokumentacja konserwatorska, t. 1 - Inwentaryzacja pomiarowo-rysunkowa, t. 2 - Badania historyczne i architektoniczne, [kps] Toruń 2008 r., archiwum MKZ Toruń sygn. 4493, 4210. W związku z tym, że autor zawarł w swojej pracy m. in. opis inwentaryzacyjny, kwe- 
Graficzną rekonstrukcję gotyckiej elewacji frontowej sporządził prof. Jan Juliusz Tajchman ${ }^{5}$.

W trakcie ostatnich badań wielu trudności w interpretacji przysporzyła liczba przebudów i zmian w obiekcie na przestrzeni lat, począwszy od połowy XIII wieku, kończąc na stuleciu XX. Ostatecznie bryła budynku pozostała średniowieczna - za wyjątkiem klasycystycznego szczytu frontowego. Strefa środkowa fasady jest gotycka, a parter pochodzi z XIX i początku XX wieku (il. 1). Elewacja tylna ze średniowiecznym szczytem posiada dziewiętnastowieczne otwory (il. 2). W układzie wnętrza czytelne są elementy wszystkich etapów budowy.

\section{ROZWARSTWIENIE HISTORYCZNE BUDYNKU GOTYK}

Kamienica już w okresie średniowiecznym (od połowy XIII do XV wieku) przebudowywana była co najmniej pięć lub sześć razy. Ilość zmian i przemurowań, ich rodzaj (różnice w formacie cegieł, sposobie murowania i opracowania spoin), jak również wtórne użycie gotyckich cegieł, utrudniały miejscami ustalenie jednoznacznej chronologii budowy. Z tego samego względu trudny do ustalenia był też dawny poziom stropów w obu traktach, szczególnie w trakcie frontowym parteru, gdzie musiała znajdować się duża sień.

Pierwszy budynek w tym miejscu mógł być wzniesiony po połowie XIII wieku. Uwzględniając wyniki ostatnich badań dendrochronologicznych ${ }^{6} \mathrm{z}$ datowaniem niektórych belek jednego ze stropów kamienicy (obecnie podłogi drugiego piętra traktu tylnego - 3.26, il. 10), można hipotetycznie przyjąć rok 1266 jako przybliżony czas powstania budynku. Ze względu na najstarsze relikty obiektu, zachowane w trakcie tylnym oraz prawdopodobny ich brak w trakcie frontowym, trudno określić, jak wyglądała albo czy w ogóle na początku istniała zabudowa obecnego przedniego traktu. Niewykluczony jest wariant, że pierwsza zabudowa obejmowała tylko trakt tylny, który był dłuższy o ok. $1 \mathrm{~m}$ od strony frontowej (w piwnicy zachowany jest ślad po pierwotnym murze poprzecznym $-0.02,0.03,0.21)$. Nad piwnicą krytą dzisiejszym sklepieniem kolebkowym (0.28), było wówczas prawdopodobnie wysokie przesklepione pomieszczenie parteru, nietypowe dla traktu tylnego toruńskich kamienic - na obecnym pierwszym piętrze są ślady $(2.28,2.41)$ po dwuprzęsłowym sklepieniu krzyżowym lub kolebkowym z lunetami - il. 7-8. Ściany wnętrza nie były wtedy tynkowane, a spoiny starannie opracowane. W murze wsch. w osi przęseł sklepiennych zachowały się ówczesne wnęki: jedna w części pn. (2.32), zamknięta łukiem dwuspadowym ściętym, druga w części pd. (2.31) zamknięta łukiem odcinkowym spłaszczonym. Liczne przemurowania przeciwległego muru zach. tego pomieszczenia i niemożliwość (ze względu na resztki polichromii) całkowitego usunięcia tynku, nie pozwalają na ustalenie pierwotnego wyglądu tej strony. Wyżej mieściła się strefa poddasza, krytego dwuspadowym dachem, usytuowanym niżej od obecnego (il. 11). Nie ma pewności, czy obecny mur tylny wraz ze śladem pierwot-

rendę archiwalną, analizę materiału badawczego itp., w uzupełniającym opracowaniu pominięto te punkty, odsyłając do ww. dokumentacji.

5 Por. artykuł tegoż autora w niniejszym tomie.

6 KONIECZNY 2011, s. 3-4. 
nego dwuspadowego szczytu (4.15), pochodzi z omawianego pierwszego etapu, czy może już z czasu, gdy zlikwidowano sklepienia na parterze. W trójkątnym szczycie elewacji tylnej pośrodku znajdowało się zamknięte dwuspadowo okno poddasza (4.16). Nie wiadomo jak w tym czasie mogła wyglądać elewacja frontowa. Przyjmując hipotezę, że jednak od początku istniała zabudowa przedniego traktu, można wysnuć wniosek, iż jego konstrukcja była drewniana lub szkieletowa, co wyjaśniałaoby brak zachowanych śladów. Analiza piwnicznego muru wschodniego w tylnym odcinku traktu frontowego dostarcza niejednoznacznych przesłanek, wskazujących na występowanie od początku zabudowy w tej części (do ewentualnego stwierdzenia w trakcie prac remontowych).

W następnym - drugim etapie gotyckim, podczas przebudowy podwyższono budynek wykonując dzisiejszy szczyt tylny (4.12) i wprowadzając zapewne nową więźbę (z tego czasu zachowało się pięć tylnych wiązarów na poddaszu - 4.06). Otwory w szczycie $(4.14,4.17)$ znajdowały się prawdopodobnie od początku w aktualnym miejscu (istniejące okna mają przemurowane krawędzie). Utrzymano wówczas pierwotny mur poprzeczny, czego dowodzą $\mathrm{m}$. in. wnęki zachowane w trakcie tylnym parteru po stronie zachodniej (1.34) i na drugim piętrze po stronie wschodniej (3.28). Dotychczasowe wysokie pomieszczenie parteru podzielono na dwie kondygnacje, likwidując sklepienie i wykonując drewniane stropy - być może obecna podłoga brusowa drugiego piętra (3.26, il. 10) funkcjonowała wtedy jako strop (wg badań dendrochronologicznych drewno datowane jest na $1266 \mathrm{r}$.). W murze tylnym na pierwszym piętrze pośrodku wprowadzono nowy otwór okienny, którego łuk odciążający widoczny jest dzisiaj nad podłogą drugiego piętra (3.37). Po stronie zachodniej tylnego pomieszczenia pierwszego piętra wykonano kominek (2.43), po którym pozostał komin, widoczny na kolejnej kondygnacji (il. 9) i poddaszu (2.44, 3.41, 4.19). $\mathrm{Na}$ drugim piętrze po stronie wschodniej przy murze tylnym ulokowano narożny kominek (widoczne ślady po okapie - 3.31, 3.35 oraz komin - 4.13). Ściany wewnętrzne kamienicy pokryto tynkiem lub cienką zaprawą.

Z kolejnych faz (3-4) pochodzi dzisiejszy trakt frontowy. Stary mur poprzeczny rozebrano i o około $1 \mathrm{~m}$ dalej w kierunku tylnym wybudowano obecny mur międzytraktowy, zachowany do pierwszego piętra włącznie $(0.25,1.24,2.22)$. Skracając w ten sposób dotychczasowy trakt tylny, ścięto w piwnicy południowy odcinek kolebkowego sklepienia traktu tylnego (0.28). Odsadzka pozostała po tej części kolebki widoczna jest w murze zachodnim (0.02). W nowym murze międzytraktowym wykonano przejście zamknięte łukiem pełnym (0.26). Początkowo w trakcie frontowym piwnicy planowano sklepienie, o czym świadczy nisko położona odsadzka w murze zachodnim (0.06), ślad przeciwległej odsadzki w murze wschodnim (0.19) oraz ślady w murze frontowym (0.13). Wkrótce zrezygnowano ze sklepienia i wprowadzono dzisiejszy strop belkowy - belki (0.08) według badań dendrochronologicznych datowane są na $1375 \mathrm{rok}^{7}$. Prawdopodobnie nieco później, około $1400 \mathrm{roku}$, od strony zach. podparto je drewnianymi stemplami (0.09) ustawionymi na odsadzce (0.06) i leżącej na niej drewnianej belce. W narożniku południowo-wschodnim w murze frontowym umieszczono szyję piwniczną $(0.16)$ ze schodami. Być może równocześnie istniały

7 KONIECZNY 2007, sygn. 3803, s. 1-2. 
wewnętrzne schody do piwnicy ulokowane w narożniku północno-zachodnim traktu, czyli w miejscu dzisiejszym, z tym że ich bieg był zapewne inny i bardziej stromy.

Możliwe, że to właśnie w tym czasie (ewentualnie we wcześniejszym etapie?) w północno-zachodnim narożniku traktu tylnego piwnicy urządzono piec (0.33) do ogrzewania izby tylnej parteru, wykuwając partię kolebki, przesklepiając na nowo i zabudowując narożnik ściankami (il. 3). W sklepieniu pieca pozostał kamień z kolistym otworem (0.34), przez który przedostawało się na parter gorące powietrze (il. 4), a powyżej, pod drewnianą podłogą parteru, ceglana posadzka $\mathrm{z}$ otworami i promieniście rozmieszczonymi kanałami grzewczymi (1.39). Do narożnika pn.-zach. traktu dobudowano w związku z tym nieduże pomieszczenie piwniczne (0.39) pełniące zapewne funkcję komory palacza, dostępne prawdopodobnie od strony podwórza. Nad obecnym przejściem (0.35), w narożniku pn.-zach. traktu tylnego piwnicy, zachował się zamurowany otwór - górne okienko (0.36) między komorą palacza a piecem.

Późniejsze przebudowy murów bocznych kamienicy uniemożliwiły ustalenie poziomu ówczesnego stropu wysokiej sieni parteru, jak też ewentualnej antresoli. Przypuszczalnie wysokość przedniego traktu była zbliżona do obecnej. Prawdopodobnie z tego etapu budowlanego pochodzi częściowo mur boczny wschodniego traktu frontowego (szczególnie na pierwszym piętrze). Zachowały się w nim ślady po pierwotnych belkach stropowych pierwszego piętra (2.16), umieszczonych nieznacznie niżej niż dzisiejszy strop oraz na drugim piętrze ślad po dawnym stropie w postaci odkrytego spod nowożytnego zamurowania fragmentu średniowiecznej murłaty (3.17). Strop drugiego piętra mógł być na jednym poziomie w obu traktach. Niewykluczone, że do tego etapu należy również siedem frontowych wiązarów dachu, które później zostały skrócone podczas podnoszenia stropu.

Nie wiadomo dokładnie, gdzie na parterze znajdowało się pierwotne kuchenne urządzenie ogniowe. Wschodni mur boczny parteru, który w trakcie frontowym w dużej części ma wtórne lico (1.17), w odcinku tylnym traktu jest starszy (1.18), lecz liczne przemurowania zatarły ewentualne ślady zarówno po wcześniejszym murze poprzecznym, jak też po piecu kuchennym. Niewykluczone, że piec od początku ulokowano właśnie tu, w narożniku północno-wschodniego traktu, gdzie potem przez długie lata był utrzymany ulegając różnym przekształceniom. W murze międzytraktowym zachowała się pozostałość półkoliście zamkniętej wnęki o fazowanych krawędziach (1.25), której istnienie nie wyklucza występowania przy niej pieca (il. 5). Przejście do tylnego traktu musiało być usytuowane dalej, w zachodniej części muru. W odcinku środkowym na wysokości około dwóch metrów znajdowało się niewielkie ostrołukowe okienko (1.30) lub wnęka (być może „przyschodowa”?). Pomieszczenie traktu tylnego na pierwszym piętrze, z wejściem w miejscu obecnym (zachowana fazowana krawędź otworu - 2.25), doświetlało jedno duże okno pośrodku elewacji tylnej (3.37). Obok wejścia od strony traktu frontowego znajdowała się nieduża wnęka o fazowanych krawędziach (2.24).

Piąty etap gotycki to czas, w którym przebudowano partię naziemną zachodniego muru, tworząc na parterze obecną dużą wnękę wysokiej sieni (1.03) i obok dwie mniejsze (1.05, 1.06), a na piętrze wnękę i kominek (2.05, 2.06 - il. 6). Poziom kominka świadczy, że strop wysokiej sieni musiał znajdować się tylko nieznacznie niżej od dzisiejszego. Strop pierwsze- 
go piętra wówczas podniesiono i ulokowano na obecnym poziomie, zamurowując w murze wschodnim gniazda belek (2.16) dotychczasowego stropu. Poziom stropu drugiego piętra utrzymano.

W ostatniej, szóstej fazie średniowiecznej wzniesiono dzisiejszy mur frontowy. Na parterze po stronie zach. umieszczono ostrołukowy portal, obok po stronie wschodniej okno wysokiej sieni - prostokątne, zwieńczone odcinkowym łukiem odciążającym. Na piętrach były okna w dzisiejszych profilowanych wnękach (niewykluczone, że w osi środkowej znajdowała się tylko blenda). Całość wieńczył schodkowy szczyt trójosiowy z tynkowanymi blendami i jednym oknem pośrodku ${ }^{8}$. Podczas powojennego remontu, częściowo rekonstruującego tę elewację, przywrócono profilowane wnęki na piętrach. Profile z ceglanych kształtek zachowały się także wewnątrz w łukach nad oknami pierwszego piętra (2.11). Na parterze jako świadki pozostały jedynie relikty łuków portalu i okna wysokiej sieni. Wyżej przywrócono tynkowy fryz ujęty w dwa pasy ceglane. Podobny pas znajduje się nad oknami drugiego piętra. Szczytu schodkowego nie odtworzono. Podczas prac w 1957 roku odkryto, że fasada malowana była na czerwono i zdobiona ornamentem geometrycznym ${ }^{9}$.

Nie wiadomo dokładnie, na którym etapie tylną izbę parteru przykryto obecnym polichromowanym stropem z dyli o grubości $7 \mathrm{~cm}$ (1.37), podpartym dwiema fazowanymi belkami ${ }^{10}$. W murze tylnym po stronie wsch. (w miejscu obecnym) znajdowało się wyjście na podwórze (obok drzwi obecnych zachowała się od zewnątrz fazowana krawędź dawnego otworu - 1.42 - średniowieczna lub nowożytna).

\section{OKRES NOWOŻYTNY (XVI W. - PIERWSZA POŁOWA XVIII W.)}

W okresie nowożytnym w kamienicy miały miejsce zmiany związane m.in. z nowym systemem ogrzewania. Wprowadzano piece kaflowe likwidując kominki. Niektóre kominki zamieniono na wnęki (2.05, 2.14 i prawdopodobnie 2.45). Przestało też wówczas funkcjonować średniowieczne ogrzewanie podłogowe w izbie tylnej parteru. Zlikwidowano więc piec w trakcie tylnym piwnicy (0.33) oraz jego ściany wschodnią i południową, a komora palacza stała się zwykłym pomieszczeniem piwnicznym. Przebudowano ją do stanu dzisiejszego wykonując nowe sklepienie i komunikując z tylnym traktem piwnicy przejściem (0.35) w miejscu dotychczasowego otworu do paleniska pieca. Umieszczony wyżej dawny otwór (0.36), prowadzący do górnej części pieca, zamurowano. W etapie nowożytnym przebudowano również piwniczny otwór okienny (0.32) pośrodku muru tylnego.

Prawdopodobnie kilka razy w tym okresie we frontowym trakcie parteru zmieniano piec kuchenny lub inne urządzenia ogniowe, wykonując ostatecznie piec z dużym okapem, którego ślady widoczne są w murze wschodnim i międzytraktowym $(1.20,1.27)$, w narożniku północno-wschodnim traktu. Partia wschodniego muru w tej części ma ślady wielu przemurowań nowożytnych związanych z piecem kuchennym i kominami.

8 Rekonstrukcja wg prof. J. Tajchmana.

9 PASZKOWSKI 2008, t. 2, s. 28.

10 Badania dendrochronologiczne wykazały, że brusy pochodzą z różnego czasu - od 1286 do 1375 r. (KONIECZNY 2011, s. 2-3). 
Wymieniono także stropy, pozostawiając tylko gotycki strop w piwnicy (0.08) i w trakcie tylnym parteru (1.37). W trakcie frontowym parteru wykonano nowy strop - najpierw na niższym poziomie (prawdopodobnie pozostałością po nim jest belka (1.12) osadzona w murze frontowym, datowana na 1721 rok $)^{11}$, potem, jeszcze w XVIII wieku, ulokowano wyżej dzisiejszy strop (1.10) i ozdobiono go polichromią z motywami rocaillu. Wraz z ostateczną zmianą stropu przemurowano partię lica muru wschodniego (1.17). Fazowane belki obecnego stropu pierwszego piętra (2.08) przypuszczalnie osadzono w poziomie stropu średniowiecznego.

Nie wiadomo dokładnie, kiedy miało miejsce podwyższenie stropu we frontowym trakcie drugiego piętra. Nie można wykluczyć, że nastąpiło to dopiero w okresie nowożytnym, gdyż zapewne $\mathrm{z}$ tego czasu pochodzi zachowany odcinek murłaty w tylnej części muru (3.18) i wnęka poniżej (3.20). Nowa wówczas murłata mogła też mieć związek z licznymi przemurowaniami kominowymi i wykonaniem czterech nowych wiązarów (4.05), które są datowane na 1743 rok $^{12}$. W tylnym trakcie drugiego piętra belki i zapewne deski obecnego stropu (3.32) pochodzą z początku XVIII wieku, lecz zostały użyte wtórnie w okresie klasycystycznym. Być może znajdowały się wcześniej właśnie w tym pomieszczeniu (?). Cechy nowożytne posiada też strop na pierwszym piętrze tylnego traktu (2.33). Może być barokowy bądź klasycystyczny, z możliwością wtórnego użycia belek. Do mniej znaczących zmian można zaliczyć prawdopodobne zamurowanie lub przekształcenie niektórych wnęk.

Trudno określić jak dalece zmieniono w tym czasie elewację frontową, gdyż poważniejsza modernizacja mogła nastąpić dopiero w okresie klasycystycznym. Być może jednak już wtedy przebudowano gotycki szczyt, a na parterze fasady powstało nowe wejście na osi środkowej zwieńczone łukiem odcinkowym, który widoczny jest nad obecnym wejściem do sklepu.

\section{KLASYCYZM (DRUGA POŁOWA XVIII - PIERWSZA POŁOWA XIX W.)}

Najpóźniej w tym okresie zmieniono wygląd elewacji frontowej. Główne wejście do budynku znajdowało się pośrodku, a po stronie wschodniej, pod oknem parteru, mieściło się frontowe wejście do piwnicy, ze schodami na wprost otworu. Tynkowana elewacja otrzymała klasycystyczny wygląd, z prostokątną ścianką parawanową szczytu (4.01) i naczółkiem dachu (4.04). Parter nad gładkim cokołem otrzymał boniowanie. Wszystkie otwory w układzie trzyosiowym były prostokątne, za wyjątkiem wejścia do piwnicy (0.16), zamkniętego odcinkowo. W szczycie pośrodku znajdowało się okno (4.02), a po bokach dwie blendy. Prawdopodobnie w tym okresie dobudowano szkieletową dwukondygnacyjną niepodpiwniczoną oficynę boczną, przylegającą do narożnika wschodniego tylnej elewacji kamienicy. Na każdym poziomie oficyna została skomunikowana $\mathrm{z}$ budynkiem głównym przejściem w elewacji tylnej $(1.43,2.35)$.

Z tego czasu pochodzi ostateczny układ wnętrza kamienicy, z zachowaniem dawnej różnicy poziomów w obu traktach. Trakt tylny drugiego piętra oddzielono obecną ścianą szkie-

11 TAMŻE, s. 2.

12 TAMŻE, s. 5. 
letową (3.23). Wraz ze ścianą zbudowano obszerny komin (3.22), z którego obsługiwano palenisko pieca grzewczego. Od razu lub nieco później izba tylna drugiego piętra otrzymała równoległą do zachodniej ściany bocznej ściankę szkieletową (3.39), pośrodku której umieszczono wnękę szafkową (3.40) z zachowaną dwuskrzydłową klasycystyczną stolarką drzwiową (il. 9). W elewacji tylnej wykonano pośrodku nowe okno (3.36). Zapewne wtedy też położono tu aktualny strop belkowo-deskowy (3.32), a deski oparto na listwach przybitych do boków belek i podbito pułapem deskowym w konstrukcji nakładkowej. Na pierwszym piętrze, w związku z powstaniem oficyny, zrezygnowano z gotyckiego okna pośrodku muru tylnego wykonując po stronie wsch. przejście (2.35), a obok nowe okno (2.37).

Najpóźniej w tym okresie w tyle frontowego traktu wydzielono murem (2.17) trakt komunikacyjno-kominowy. Na parterze (ok. 1800 r.) zlikwidowano piec kuchenny z dużym okapem, a kuchnię przeniesiono na parter oficyny. W pionie dotychczasowego pieca kuchennego w północno-wschodnim narożniku traktu frontowego zbudowano wtedy obecny komin (1.22 - il. 5) dla pieców grzewczych, z komorą do obsługi paleniska. Nie wiadomo, czy dopiero wówczas wykonano pod spodem w narożniku piwnicy dodatkowe belkowanie (0.23) pod stropem, czy miało to miejsce już w poprzednim okresie. W narożniku postawiono także murowany słup wzmacniający $(0.22)$.

W fazie klasycystycznej wykonano schody, które z czasem (być może w pierwszej połowie XX wieku) nad parterem zmieniły swój układ, a stare elementy przeniesiono, zapewne uzupełniając nowymi. Osiemnastowieczna balustrada o charakterze barokowym zachowała się na parterze (1.04) oraz na drugim piętrze (3.04). Balaski deskowe mają ślady polichromii iluzjonistycznej ${ }^{13}$. Z tego okresu pochodzą również schody do piwnicy $(0.11)$ wraz ze stojącą obok ścianką szkieletową (0.12). Może też jednocześnie wzniesiono w piwnicy masywny filar (0.24), lub powstał on jeszcze w czasie, gdy na parterze znajdował się piec kuchenny.

Wnętrza - ściany i stropy - były bogato zdobione. Na parterze w tylnym trakcie stary strop (1.37) pokryto płótnem, które ozdobiono polichromią. Po jakimś czasie płótno przemalowano, wykonując dekorację klasycystyczną (XVIII w. lub ok. 1800 r.), z motywem waz powtarzających się w trzech polach stropu, między stropowymi belkami. Każde pole otoczono profilowaną listwą. Tynkowaną ścianę w pasie pod stropem ozdobiono malowaną roślinno-geometryczną bordiurą. Najpóźniej około połowy XIX wieku stropy podbito podsufitką i otynkowano, za wyjątkiem części komunikacyjnych, frontowego traktu drugiego piętra oraz piwnicy.

Zmiany wnętrz w tym okresie dotyczyły także wnęk. Niektóre zostały zamurowane (np. 3.20), inne przerobione na mniejsze wnęki szafkowe (1.45). Plan z 1848 roku pokazuje występowanie wnęk także na parterze w trakcie tylnym po stronie wschodniej i zachodniej. Według opisu w ścianach bocznych izb frontowej i tylnej pierwszego piętra umieszczone były po dwie szafki ścienne. W tym okresie właścicielem był piernikarz Wentscher, stąd na zapleczu działki znajdowały się piekarnia i pakowalnia ${ }^{14}$.

13 Izabela HUK-MALINOWSKA, Anna KRIEGSEISEN, Dokumentacja badań konserwatorskich malarskiego wystroju wnętrza przeprowadzonych w kamienicy przy Rynku Staromiejskim 20 w Toruniu, [kps] Gdańsk 2008 r., archiwum MKZ Toruń, sygn. 4211, s. 14-20.

14 PASZKOWSKI 2008, t. 2, s. 16-17. 


\section{DRUGA POŁOWA XIX - PIERWSZA POŁOWA XX W.}

W 1864 roku właścicielem posesji został mistrz rzeźnicki (A. Muller) ${ }^{15}$, który na parterze kamienicy w północno-wschodniej części frontowej urządził sklep, a z lewej - zachodniej strony wydzielił korytarz klatki schodowej. Niewykluczone, że wówczas zlikwidowano początkowy zakręt schodów, widoczny na planie z 1848 roku. Wejście główne do kamienicy ulokowano w miejscu obecnym, a pośrodku umieszczono drzwi do sklepu.

W drugiej połowie XIX wieku wprowadzono nowe stolarki okienne. Wówczas wykonano drobne zmiany przy węgarach okiennych. Prawdopodobnie wtedy też zamurowano wnęki pod oknami frontowymi na pierwszym piętrze. Pozostałe jeszcze odsłonięte stropy belkowe w tym okresie podbito podsufitką i otynkowano. W 1902 roku przebudowano parter wykonując nowe drzwi do sklepu i witrynę wraz ze stolarką w miejscu poprzednio mniejszego okna. Obecną stolarkę drzwi frontowych (1.14) wprowadzono przypuszczalnie pod koniec XIX wieku lub na początku XX wieku. Mniej więcej w tym czasie zlikwidowano frontowe wejście do piwnicy (0.16), zamieniając je na okno. Zakład rzeźnicki na terenie parceli istniał do 1908 roku.

Na początku XX wieku, w związku z przekształceniem budynku na kamienicę czynszową, zmieniono układ schodów, wykonując dzisiejszą ciasną klatkę. Częściowo zachowano stare schody z deskowymi balaskami, dziś widocznymi na parterze i drugim piętrze. W 1919 roku otynkowano fasadę. Być może wówczas lub w latach dwudziestych fasada otrzymała wystrój w postaci tynkowych płycin w osiach okiennych i boniowania. W 1938 roku w ramach remontu fasady usunięto z niej tynk, lecz z powodu wojny prace nie były kontynuowane.

\section{DRUGA POŁOWA XX - POCZĄTEK XXI WIEKU}

Około połowy XX wieku rozebrano jednopiętrową oficynę boczną i zamurowano przejście na pierwszym piętrze tylnego muru kamienicy. W latach 1957-1961 przeprowadzono renowację fasady, nadając jej obecny wygląd i przywracając na piętrach gotyckie profilowane wnęki ${ }^{16}$.

W 1979 roku przeprowadzono remont stolarek okiennych i drzwiowych. W 1993 roku miał miejsce remont kapitalny wraz z więźbą, skróceniem krokwi, a przez to - podwyższeniem pomieszczenia traktu frontowego drugiego piętra i wprowadzeniem dzisiejszego stropu (3.09). Więźbę wzmocniono za pomocą stalowych kleszczy przymocowanych do nowej żelbetowej murłaty. Dach pokryto nową dachówką "holenderką”. Uzupełniono ubytki fasady, oczyszczono ją i przemurowano nadproża okien. Skuto stary tynk elewacji tylnej i otynkowano na nowo. Na parterze przemurowano lico dużej wnęki gotyckiej (1.03) w murze zachodnim traktu frontowego. Z czasów współczesnych pochodzą wszystkie stolarki okienne i kilka drzwiowych. Obecna witryna i drzwi do sklepu zostały wprowadzone w miejscu

15 TAMŻE, s. 22.

16 TAMŻE, s. 28. 
poprzedniej stolarki z 1902 roku. Współczesne podziały usunięto w trakcie ostatnich prac odkrywkowych i zabezpieczających.

Przedstawiona kamienica jest tylko jednym z przykładów, które dowodzą, jak wiele wartościowych historycznych elementów, i jak wiele zagadek kryją w sobie jeszcze kolejne, nieprzebadane obiekty, należące do materialnego dziedzictwa Torunia. I choć budowlana aktywność dawnych właścicieli często „utrudnia życie” badaczowi, to na pewno jest potem niezwykłym źródłem wiedzy, które ułatwia następne zadania. Gruntowna analiza obiektu pozwala miedzy innymi na wyciągnięcie właściwych wniosków, niezbędnych dla opracowania wytycznych konserwatorskich, które mogą "przedłużyć życie” zabytkowi. Nasze dokumentacje dodatkowo bywają ostatnią formą utrwalenia tego, czego - z różnych względów nie da się już uratować, lub dają szansę na ujawnienie elementów, które zostaną wkrótce w jakiś sposób ukryte (np. pod tynkami).

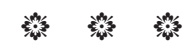

\section{Tenement House at 20, Old Market Square, Toruń. The Monument Analysis of the Building.}

The article was based on the documentation ${ }^{17}$ prepared in 2011 on the basis of research inside the building. The tenement house described is one of the examples of how many valuable historical items and how many puzzles are concealed in yet other, unexamined objects in Torun. The difficulty of interpretation is caused by multiple stages of construction. Finally, the shape of a building is medieval while the front gable is classicist. The central part of the façade is Gothic, ground floor comes from the $19^{\text {th }}$ century and the beginning of the $20^{\text {th }}$ century. The rear elevation of the medieval gable has openings from the $19^{\text {th }}$ century. The interior includes the elements of all the stages of the construction.

The house, already in the medieval period (from the middle of $13^{\text {th }}$ to $15^{\text {th }}$ centuries) was rebuilt at least five or six times. The oldest relics of the object ( $\mathbf{1}^{\text {st }}$ stage of the construction) preserved in the rear suit (barrel vault basement $(0,28)$, traces of the vault of the ground floor $(2.28,2.41)$, traces of the rear gable (4.15). In the $2^{\text {nd }}$ Gothic stage the building is being elevated by adding today's rear gable (4.12), a high and vaulted ground floor room (unusual for the rear suite of the Torun's tenement houses) was divided into two floors. From the 3-4 $\mathbf{4}^{\text {th }}$ stage comes today's front suite with the inner wall $(0.25,1.24,2.22)$, basement ceiling $(0.08)$, timber roof truss (4.03), as well as the relics of a furnace (0.33) to heat the back ground floor room and the chamber of fireman (0.39). In the $5^{\text {th }}$ stage the western wall in the front suite was rebuilt and new ceilings were made. The last, $\mathbf{6}^{\text {th }}$ medieval stage, saw the rising of today's front wall.

During modern times $\left(16^{\text {th }}-1^{\text {st }}\right.$ half of the $18^{\text {th }}$ centuries) most of the ceilings were rebuilt,

17 TAMŻE. 
tile stoves were introduced in place of the fireplaces and the furnace in the rear ground floor room was demolished (0.33). After a few renovations a kitchen stove with a big hood was introduced on the ground floor $(1.20,1.27)$. It might have been then that the Gothic front gable was rebuilt.

In the $2^{\text {nd }}$ half of the $\mathbf{1 8}^{\text {th }}$ to the $19^{\text {th }}$ centuries the front façade was given the Classicist appearance, with rectangular openings, rectangular curtain wall of the facade (4.01) and a hip of the roof (4.04). The final layout of the interior was also determined preserving the former difference of level in both suites. From those times come the half-timbered walls (3.23, 3.39), chimneys $(3.22,1.22)$ and partially stairs with the $18^{\text {th }}$ century banister $(1.04,3.04)$.

In 1864 the main entrance to the house was located in the present place and in the middle there was a door to a shop. In the $2^{\text {nd }}$ half of the $19^{\text {th }}$ century new window framing was introduced. In 1902, the ground floor was rebuilt introducing a new door and a window to the shop. At the beginning of the $20^{\text {th }}$ century the layout of the stairs was changed by tightening the staircase. In 1919 the facade was plastered and in 1938 the plaster was removed. Between 1957-61 the facade was renovated and given today's look. In 1993 the suite of the $2^{\text {nd }}$ floor was risen and the rear wall had its plaster exchanged. 


\section{SPIS ILUSTRACJI}

1. Toruń, kamienica przy Rynku Staromiejskim 20. Elewacja frontowa, fot. E. Nawrocka.

2. Toruń, kamienica przy Rynku Staromiejskim 20. Widok ogólny na elewację tylną, fot. E. Nawrocka.

3. Piwnica, trakt tylny. Narożnik pn.-zach. - miejsce dawnego pieca do ogrzewania izby tylnej parteru. Widok na przejście w murze tylnym do piwnicy pod podwórzem. A - zamurowany otwór do górnej części pieca; $\mathrm{B}$ - fragment muru w miejscu usuniętej ściany pieca; $\mathrm{C}$ - poziom paleniska; D - sklepienie pieca, fot. E. Nawrocka.

4. Piwnica, trakt tylny. Fragment sklepienia pieca fot. 3 D, z wylotem ciepłego powietrza, fot. E. Nawrocka.

5. Parter, trakt frontowy. Widok na mur międzytraktowy. A - komin wzniesiony po likwidacji w tym miejscu pieca kuchennego; B - relikt gotyckiej wnęki; C - ślad po kapturze pieca kuchennego; D - zamurowane współcześnie dawne przejście, fot. E. Nawrocka.

6. I piętro, trakt frontowy. Widok na mur zach. A - zamurowana wnęka w miejscu wcześniejszego kominka gotyckiego; B - rolka w poziomie zamknięcia dawnego otworu kominka; C - wnęka gotycka, fot. E. Nawrocka.

7. I piętro, trakt tylny. Widok od strony pd.-zach. na mur wsch. A - ślady po sklepieniu parteru, z najstarszego etapu gotyckiego; B - lico przemurowane po likwidacji sklepienia; C - wnęka prawdopodobnie z czasu występowania sklepień; D - odsłonięta odsadzka, na której opierało się sklepienie; E - warstwy główek nad pierwotnym (ob. zamurowanym) wgłębieniem przygotowanym dla osadzenia sklepienia, fot. E. Nawrocka.

8. I piętro, trakt tylny. Część pd. muru wsch. A - ślady po sklepieniu z najstarszego etapu gotyckiego; B - lico przemurowane po likwidacji sklepienia; C - wnęka pierwotna w murze pierwszego etapu; D - odsłonięta odsadzka, na której opierało się sklepienie; E - warstwy główek nad pierwotnym (ob. zamurowanym) wgłębieniem przygotowanym dla osadzenia sklepienia, fot. E. Nawrocka.

9. II piętro, trakt tylny. Widok od strony pn.-wsch. na szkieletową ściankę równoległą do muru zach., wprowadzoną najpóźniej na pocz. XIX w. Zachowana klasycystyczna szafka ścienna. A - gotycki komin dawnego kominka niższej kondygnacji, fot. E. Nawrocka.

10. II piętro, trakt tylny, narożnik pn.-wsch. Fragment podłogi z brusów średniowiecznych (XIII w.). A - odsadzka gotyckiego muru tylnego, fot. E. Nawrocka.

11. Poddasze. Widok na szczyt tylny. A - pozostałość gotyckiego szczytu pierwotnego; B - zamurowane górne okno pierwotnego szczytu A; C - szczyt gotycki z etapu podwyższenia budynku; D - komin gotycki narożnego kominka II piętra; E - okna gotyckie szczytu C, z ościeżami przerobionymi podczas wymiany stolarki, fot. E. Nawrocka. 


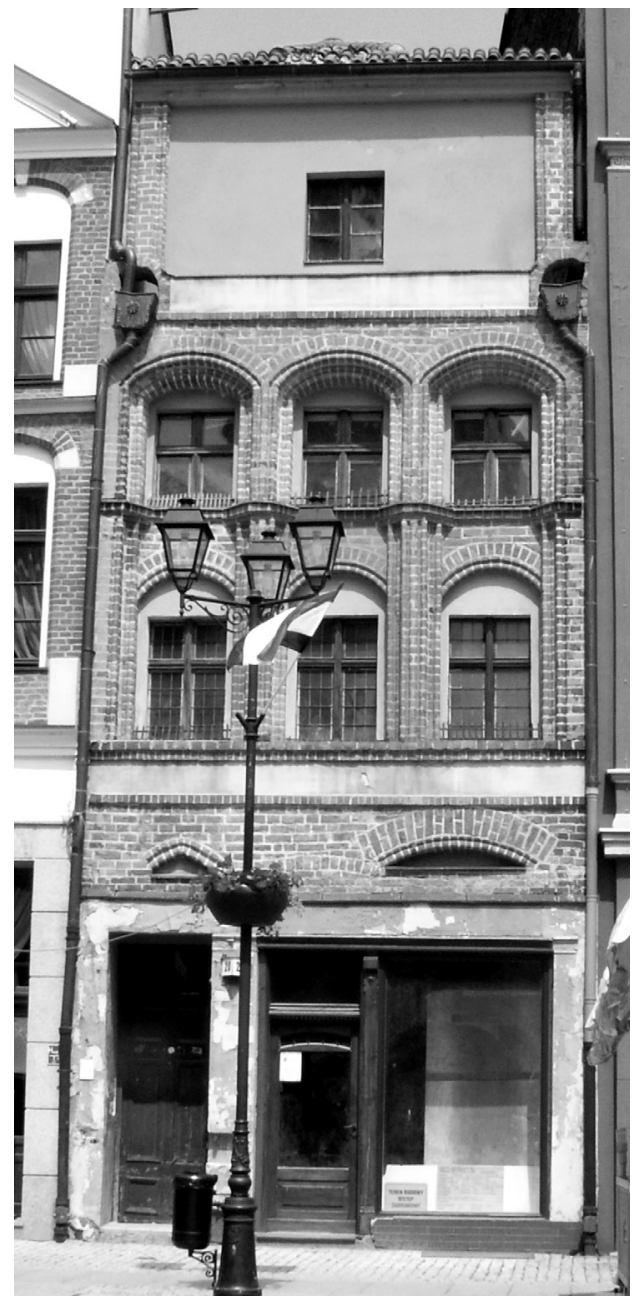

Il. 1 Toruń, kamienica przy Rynku Staromiejskim 20. Elewacja frontowa, fot. E. Nawrocka

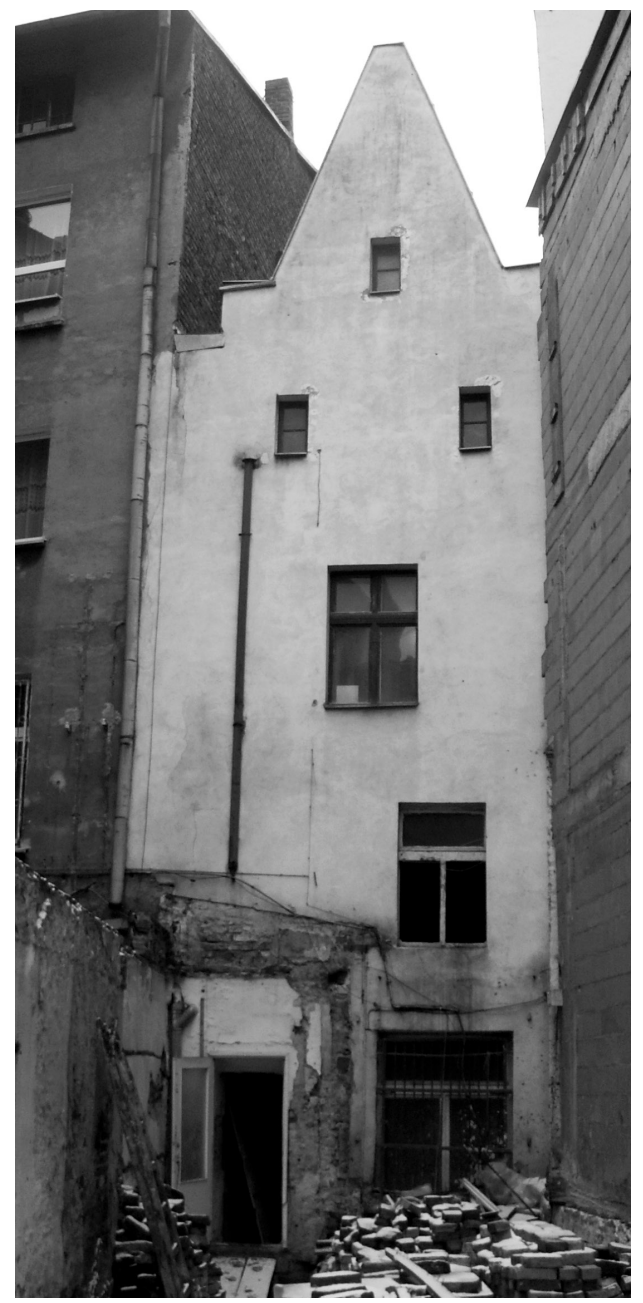

Il. 2 Toruń, kamienica przy Rynku Staromiejskim 20. Widok ogólny na elewację tylną, fot. E. Nawrocka 


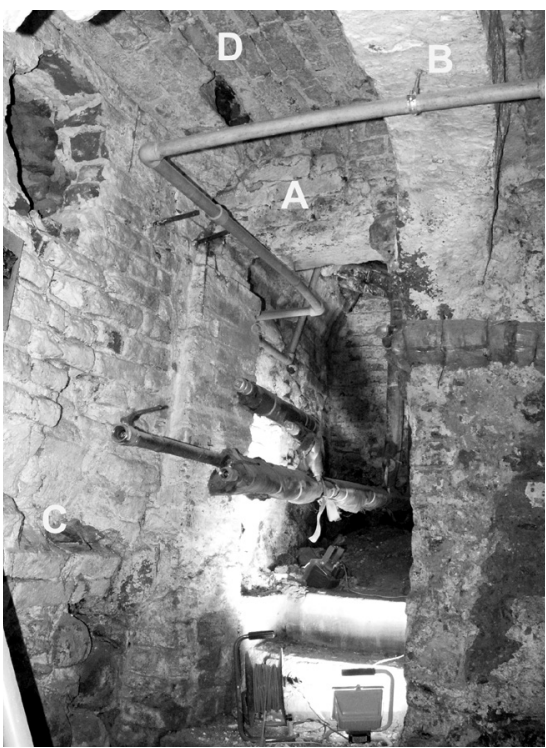

Il. 3 Piwnica, trakt tylny. Narożnik pn.-zach. - miejsce dawnego pieca do ogrzewania izby tylnej parteru. Widok na przejście w murze tylnym do piwnicy pod podwórzem. A - zamurowany otwór do górnej części pieca; B - fragment muru w miejscu usuniętej ściany pieca; $\mathrm{C}$ - poziom paleniska; D - sklepienie pieca, fot. E. Nawrocka

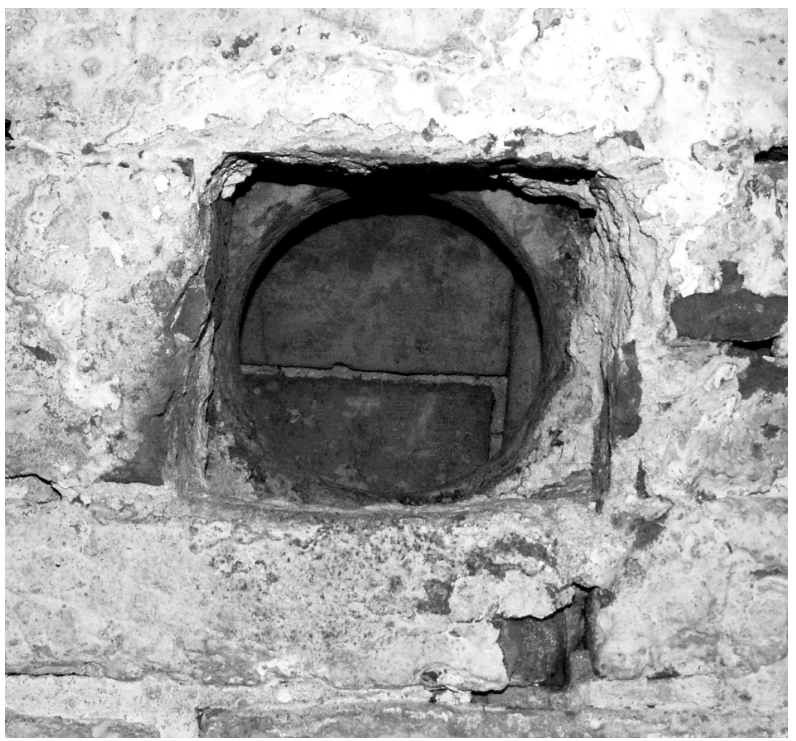

Il. 4 Piwnica, trakt tylny. Fragment sklepienia pieca fot. 3 D, z wylotem ciepłego powietrza, fot. E. Nawrocka 


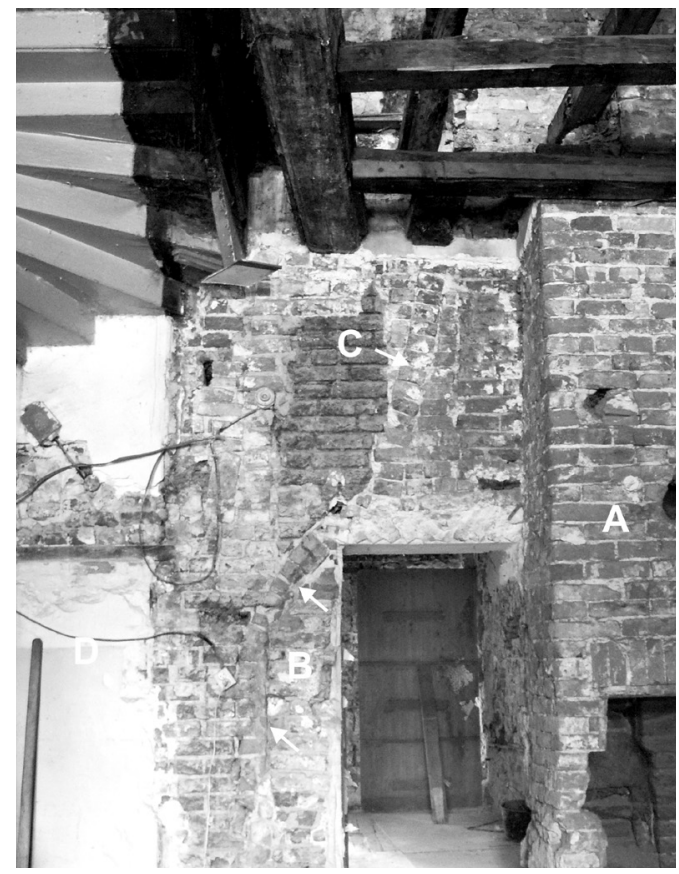

Il. 5 Parter, trakt frontowy. Widok na mur międzytraktowy. A - komin wzniesiony po likwidacji w tym miejscu pieca kuchennego; B - relikt gotyckiej wnęki; C - ślad po kapturze pieca kuchennego; D - zamurowane współcześnie dawne przejście, fot. E. Nawrocka

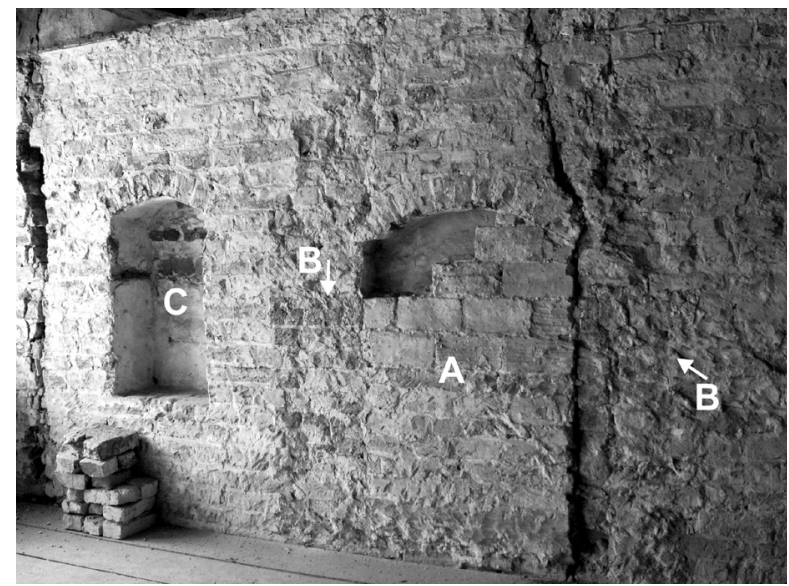

Il. 6 I piętro, trakt frontowy. Widok na mur zach. A - zamurowana wnęka w miejscu wcześniejszego kominka gotyckiego; B - rolka w poziomie zamknięcia dawnego otworu kominka; C - wnęka gotycka, fot. E. Nawrocka 


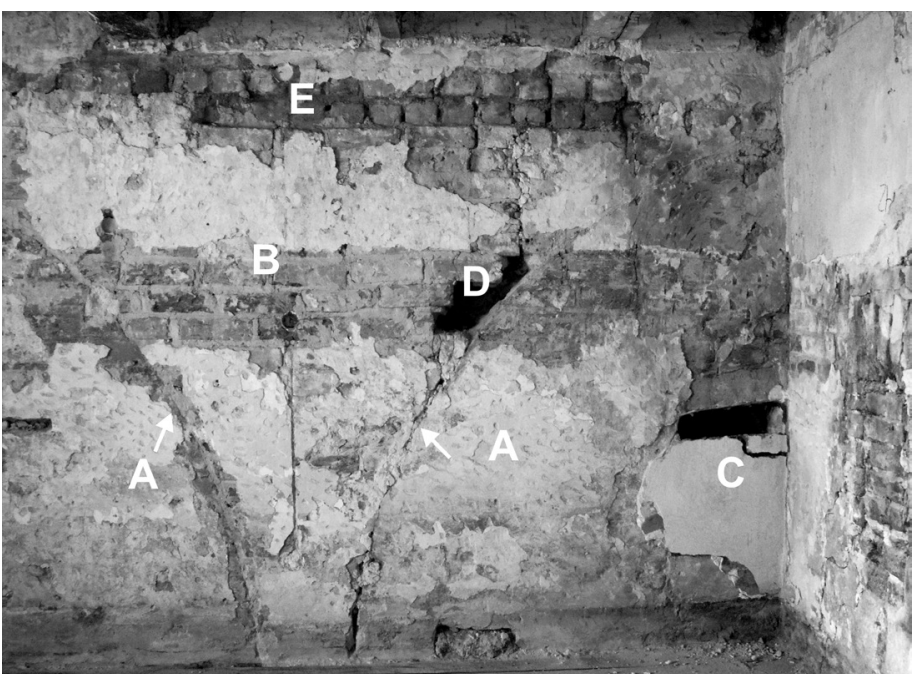

Il. 8 I piętro, trakt tylny. Część pd. muru wsch. A - ślady po sklepieniu z najstarszego etapu gotyckiego; B - lico przemurowane po likwidacji sklepienia; C - wnęka pierwotna w murze pierwszego etapu; D - odsłonięta odsadzka, na której opierało się sklepienie; E - warstwy główek nad pierwotnym (ob. zamurowanym) wgłębieniem przygotowanym dla osadzenia sklepienia, fot. E. Nawrocka

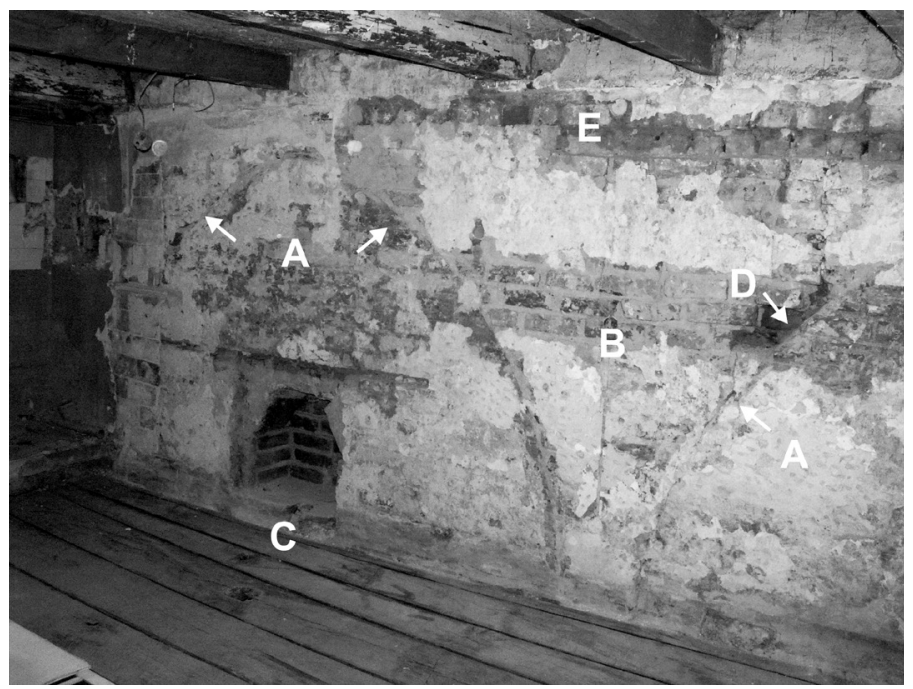

Il. 7 I piętro, trakt tylny. Widok od strony pd.-zach. na mur wsch. A - ślady po sklepieniu parteru, z najstarszego etapu gotyckiego; B - lico przemurowane po likwidacji sklepienia; $\mathrm{C}$ - wnęka prawdopodobnie z czasu występowania sklepień; D - odsłonięta odsadzka, na której opierało się sklepienie; E - warstwy główek nad pierwotnym (ob. zamurowanym) wgłębieniem przygotowanym dla osadzenia sklepienia, fot. E. Nawrocka 


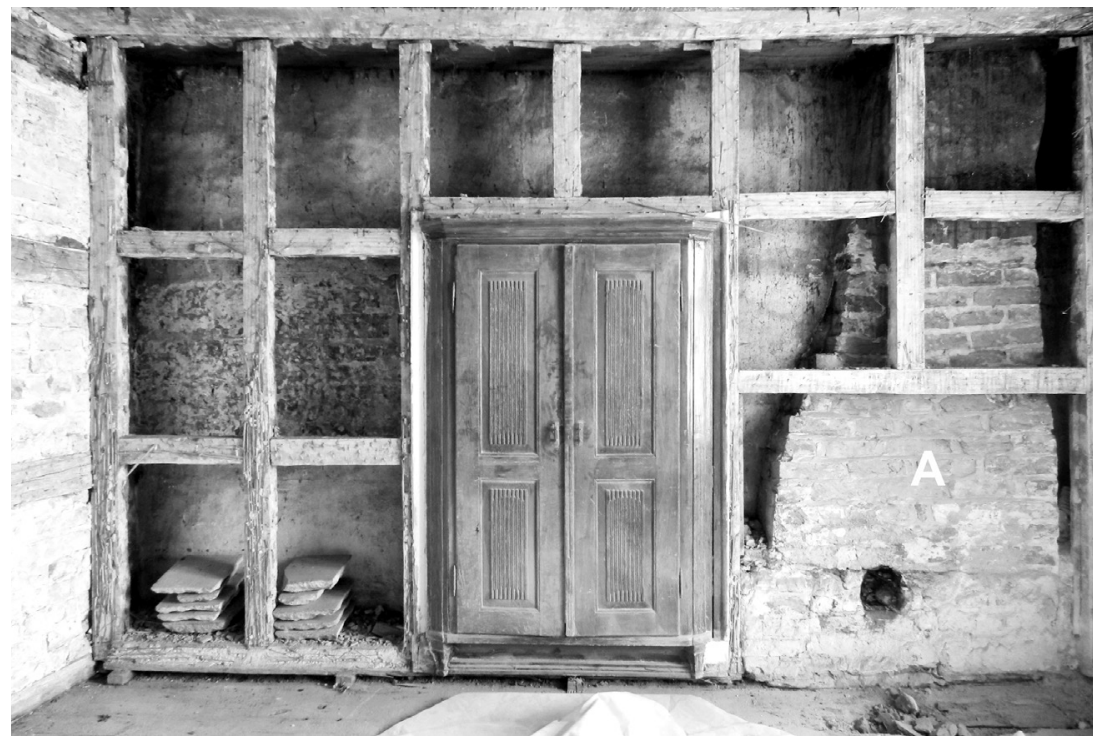

Il. 9 II piętro, trakt tylny. Widok od strony pn.-wsch. na szkieletową ściankę równoległą do muru zach., wprowadzoną najpóźniej na pocz. XIX w. Zachowana klasycystyczna szafka ścienna. A - gotycki komin dawnego kominka niższej kondygnacji, fot. E. Nawrocka

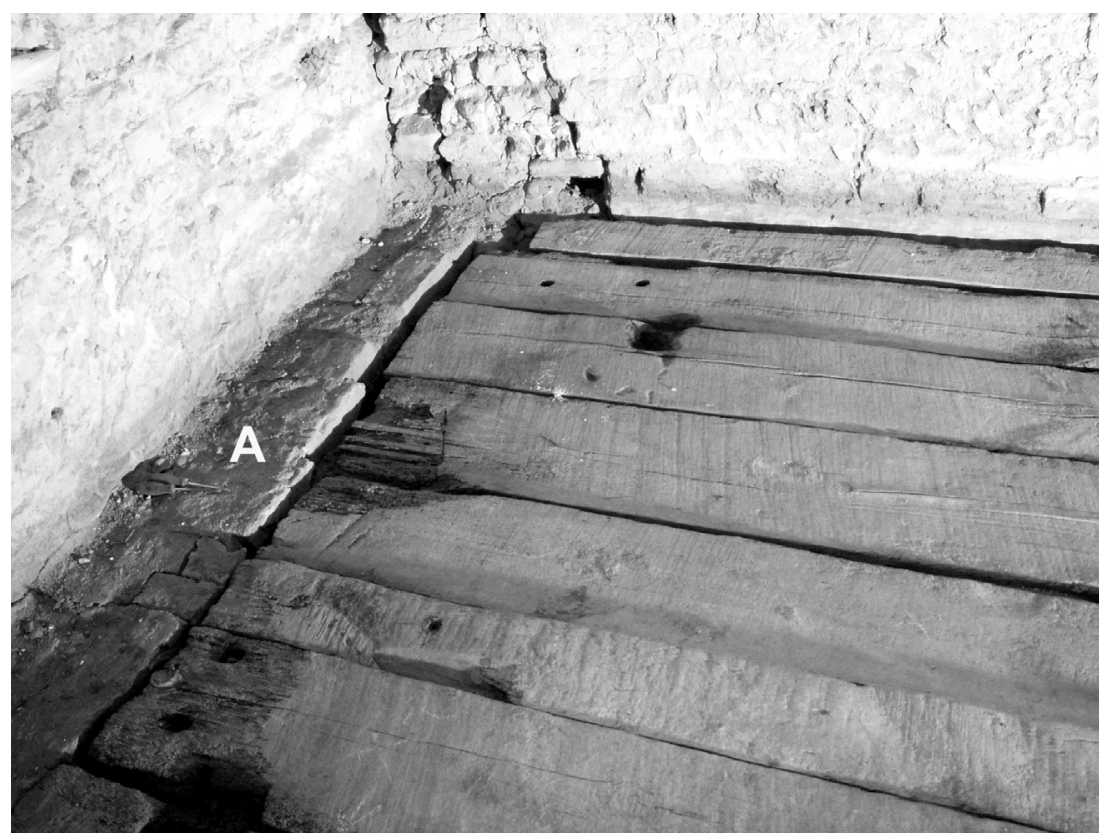

Il. 10 II piętro, trakt tylny, narożnik pn.-wsch. Fragment podłogi z brusów średniowiecznych (XIII w.). A - odsadzka gotyckiego muru tylnego, fot. E. Nawrocka 


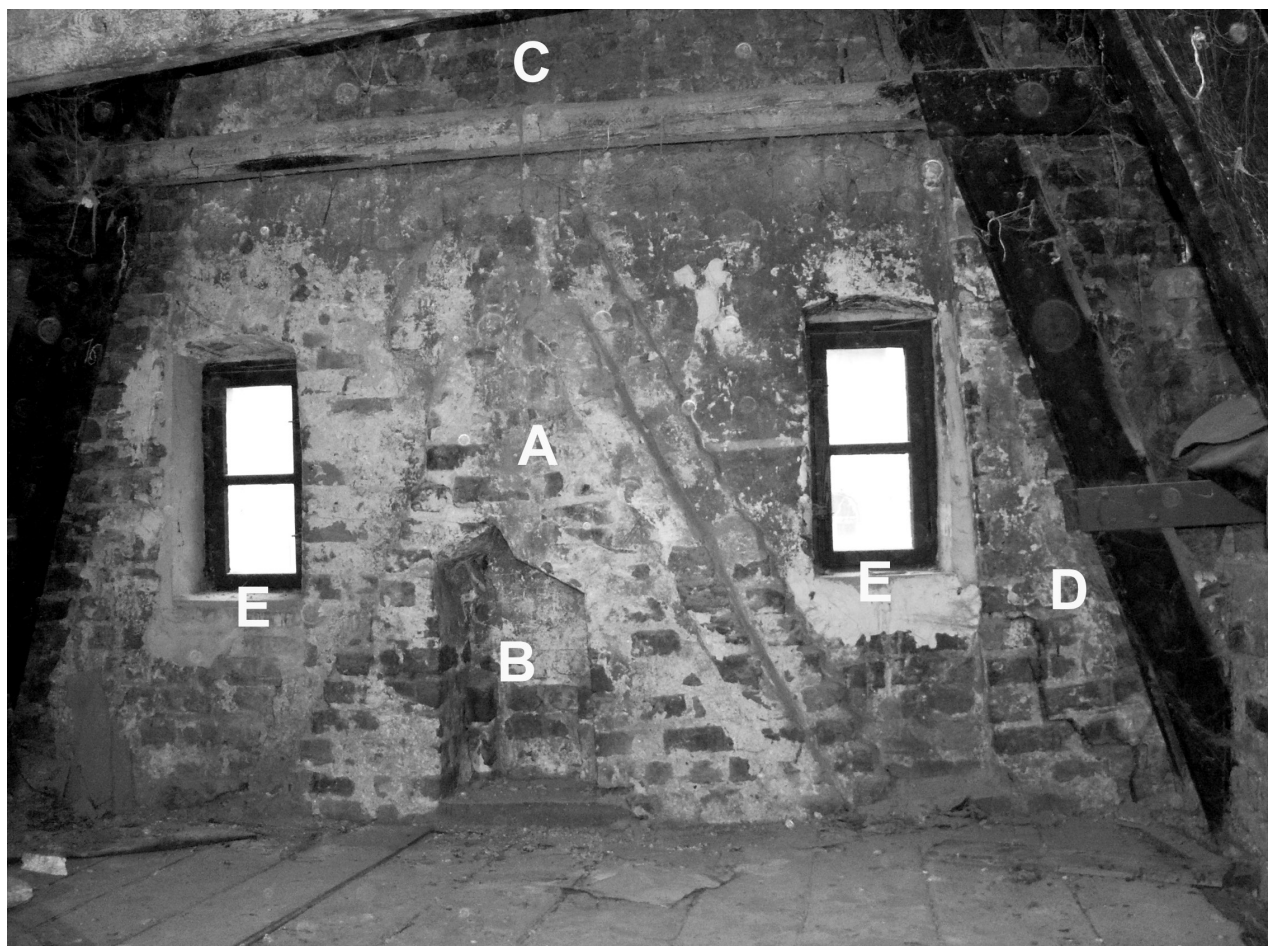

Il. 11 Poddasze. Widok na szczyt tylny. A - pozostałość gotyckiego szczytu pierwotnego; B - zamurowane górne okno pierwotnego szczytu A; C - szczyt gotycki z etapu podwyższenia budynku; D - komin gotycki narożnego kominka II piętra; E - okna gotyckie szczytu C, z ościeżami przerobionymi podczas wymiany stolarki, fot. E. Nawrocka 